\title{
Review of Eco-Friendly Biochar Used in the Removal of Trace Metals on Aqueous Phases
}

\author{
A. B. Duwiejuah ${ }^{1,2, *}$, S. J. Cobbina ${ }^{2}$, N. Bakobie ${ }^{2}$ \\ ${ }^{1}$ Department of Biotechnology, Faculty of Agriculture, University for Development Studies \\ ${ }^{2}$ Department of Ecotourism and Environmental Management, Faculty of Natural Resources and Environment, \\ University for Development Studies \\ *Corresponding author: abalu096@gmail.com
}

\begin{abstract}
Eco-friendly biochar produced from cost-effective and readily available agricultural waste will likely pose no threat on the aqueous phases, other environmental media, human health and emission of greenhouse gases to the atmosphere. Optimising biochar for an intended application could require careful selection of a biomass feedstock as well as production pyrolysis technique and conditions for the production of biochars with specific characteristics. Previous studies have explores the relationships that exist between biochar production conditions, characteristics, and possible end-uses of biochar. This review provides an overview of the production and utilisation of biochar as absorbents for adsorption of trace metals in contaminated aqueous environment. Biochar has great affinity to adsorb molecular ions that is making it possible to be used for various toxicological remediation strategies. It has proven effective and useful for mitigating aqueous metals, organic compounds, suspended solids, and organic hydrocarbons in a various kind of industrial applications such as urban and residential storm water runoff, landfill leachates, industrial runoff, resource extraction runoff, and industrial wastewater filtration. Specifically designed biochar could be very effective in the removal of trace metals from contaminated aqueous environment. The multiple factors that determine the adsorption of the trace metals in aqueous environment or phases needs to be carefully examined. Cost-effectiveness of biomass feedstock and eco-friendliness of techniques need to also be given much consideration by way of making comparison with existing contaminant mitigation technologies.
\end{abstract}

Keywords: aqueous phases, biochar, cost-effective, biomass feedstock, removal, trace metals

Cite This Article: A. B. Duwiejuah, S. J. Cobbina, and N. Bakobie, "Review of Eco-Friendly Biochar Used in the Removal of Trace Metals on Aqueous Phases." International Journal of Environmental Bioremediation \& Biodegradation, vol. 5, no. 2 (2017): 27-40. doi: 10.12691/ijebb-5-2-1.

\section{Introduction}

Biochar is produced from biomass or feedstock pyrolysis which is a process that involves breaking down of organic substances at temperatures that ranged from $350{ }^{\circ} \mathrm{C}$ to $1000{ }^{\circ} \mathrm{C}$ in a low-oxygen thermal process [1]. The pyrolysis of biomass or feedstock done under controlled conditions with clean technology and can be used for environmental restoration purpose. This makes biochar specific pyrolysis char that is characterised by their superfluous environmentally sustainable production, quality and usage features [1].

Biochar is a relatively modern development, evolving in coincidence with soil management, carbon sequestration issues, and control of pollutants [2]. Basically, guidelines are applied to differentiate between two different biochar grades thus 'basic' due to its threshold values and 'premium' because of environmental requirements. In order, to obtain European biochar certificate these criteria concerning biomass feedstock, production method, properties of the biochar and the mode of application have to be met [1].
Lately, adsorption process has positioned itself as one of the most efficient and attractive methods for removal of aqueous contaminants, due to its characteristics such as easy process control, cost-effective and efficient energy requirements [3]. The cost involved in the use of adsorption technology can be reduced provided the adsorbent is cheap [4]. It is mostly used because of its effectiveness as physical method of separation for removal or minimisation of the concentration of organics and inorganics contaminants in the aqueous environment by application of most common adsorbents which include activated carbon, aluminium oxide and silica gel [5]. Adsorption capacity of any adsorbent is influenced by its pore size, chemical structure and active sites [4].

Trace metal is defined as any metallic element with a relatively high density and toxic or poisonous regardless of its concentrations [6]. Trace metals have been the main environmental contaminants that usually pose a serious threat to human wellbeing and animal health by their continuous existence in the environment [7]. The earth's crust is natural components of trace metals [8,9]. Trace metals main characteristics include an atomic density usually greater than $5 \mathrm{~g} / \mathrm{cm}^{3}$ [10] and an atomic number less than 20 [8]. In developed and developing countries 
the most common aqueous contaminated trace metals are $\mathrm{Cd}, \mathrm{Cr}, \mathrm{Cu}, \mathrm{Hg}, \mathrm{Pb}$, and $\mathrm{Zn}$.

Basically, the occurrence of trace metals in aqueous can result from two main sources. Trace metals occur naturally can be found in aqueous environment from a pedogenetic processes that involves weathering of parent materials at levels that can be regarded as trace (less than $1000 \mathrm{mg} / \mathrm{kg}$ ) and rarely toxic [11,12]. Anthropogenic activities such as electroplating, energy and fuel production, mining, melting operations, intensive agriculture, smelting, sludge dumping, and power transmission, are the major contributor to trace metals contamination [9]. The mining sector and landfilling sites for waste are major contributing sources of trace metals contamination in aqueous environment.

\section{Biomass Feedstocks for Biochar Production in Relation to Adsorption}

Feedstock is a conventional term that often refers to the type of biomass that is pyrolysed in order to obtain a biochar [13]. Feedstock and conditions of the pyrolysis are crucial factors that depend on the various properties of any biochar produced. It can be produced from different biomass feedstocks with varied physical and chemical properties. These properties are crucial for the thermal conversion processes, principally the proximate analysis (moisture content and ash), fractions of fixed carbon, caloric value and volatile components [14], fraction of cellulose, hemicelluloses and lignin [15], percentage and composition of inorganic substance, bulk, particle size and true density.

Cellulose and lignin of a feedstock endure thermal degradation at temperatures range of $240^{\circ} \mathrm{C}$ to $350^{\circ} \mathrm{C}$ and $280^{\circ} \mathrm{C}$ to $500^{\circ} \mathrm{C}$, respectively [16]. Hence, the fractional proportions of each component on biomass feedstock determine the biomass structure that will remain after a pyrolysis process at any given temperature. This was proven by Winsley [17] where a pyrolysis of a feedstock from wood-based generated coarser and added resistant biochars with carbon contents of $80 \%$ as the unbending ligninolytic nature of the raw material remains in the biochar residue. Biomass feedstock with high lignin contents for instance olive husks has highest yields of biochar due to the stability of lignin in thermal degradation [16].

Consequently, lignin loss is typically less than half of cellulose loss in terms of comparable temperatures and residence times [16]. Biochars produced at higher temperatures are usually expected to be donors, whilst biochars produced at lower temperatures are anticipated to be $\pi$-acceptors [18]. Lignocellulosic biomass is one of the most naturally abundant occurring available raw materials, which is a preferred feedstock choice [19]. The availability of specific biochars and their economic value is influenced by temporal and spatial existence of biomass feedstock [13]. Wide-ranged of feedstock biomasses have recently been used in the production of biochar [14] these include agricultural waste [20,21], bioenergy crops (willows, miscanthus and switch grass) [22], forest residues (sawdust, grain crops, and nut shells) [23], organic waste (green yard waste and animal manure) [24,25], kitchen waste, and sewage sludge [26].
Many biomass feedstock have been used to produced biochar such as grain husks, nut shells, manure, crop residues and wood, whilst those with the highest carbon contents (for example nut shell, wood), abundance and cost-effectiveness are currently used for activated carbon production [27]. Biochar produced from agricultural waste does not cause any notable life cycle based greenhouse gas (GHG) emissions [28]. However, little is done about the usages of readily available, eco-friendly and costeffective biomass feedstocks that have the potency for effective removal of trace metals from aqueous environment (such as landfill wastewater and polluted water bodies in mining areas).

Generally, the moisture content, volatile component, and particle size and shape of biomass have effect on the property of biochar obtained. Collison et al. [29] established that within a biomass feedstock type, different composition could arise based on its growing environmental conditions that include moisture content, temperature, soil type and those relating to harvesting time with regard to the characteristics of some plant feedstocks. It is obvious that compositional heterogeneity is common within the same plant material. The suitability of each biomass feedstock type for biochar is largely dependent on a number of chemical, environmental, physical as well as economic and logistical factors [29]. Therefore, biochar produced from cost-effective and readily available groundnut and shea nut shells are likely to pose no threat on the aqueous phases, other environmental media, human health and emission of greenhouse gases to the atmosphere.

Feedstocks utilised for biochar production include crop residues, grasses, and manures and woody biomass that influence biochar characteristics such as concentrations of basic constituents, density, hardness and porosity [30]. Optimising biochar for an intended application could require careful selection of a biomass feedstock, pyrolysis technique and conditions for production of biochars with specific characteristics. Many studies have explored the relationships that exist between biochar production conditions, characteristics, and possible end-uses of biochar.

\section{Production of Biochar for Adsorption}

Biochar has different physico-chemical properties dependent on the technology deployed for its production [31]. Pyrolysis is principally based on heating in an oxygen-depleted environment. It has already been used to produce biochars for immobilisation of both inorganic and organic pollutants in aqueous phases. The traditional earthen charcoal kiln is usually used to produce biochar, where combustion, gasification and pyrolysis process are deployed in parallel below the earthen kiln layer. Whilst in modern biochar responds to pyrolysis and processes of combustion that involves physically separation of the metal barrier [32].

Pyrolysis technology is eminent by the pyrolytic temperature (for example slow and fast pyrolysis process), residence time, size of biochar adsorbent, and the heating rate, method and pressure [33]. Pyrolysis technology is differentiated based on the temperature of pyrolysis and carbonisation process or the residence time of the 
pyrolysis [32]. Pyrolysis should be done by constantly given much consideration to biochar yield, energy efficiency, trace metal stability and structure [34].

Slow pyrolysis is often referred as a continuous process that involves obtaining oxygen-free feedstock biomass by transferring into an external heated kiln or furnace (gas flow removing volatile biochar emerging at the other end). Whilst fast pyrolysis usually depends on very quick heat transfer, normally to fine biomass particles at less than $650{ }^{\circ} \mathrm{C}$ with rapid heating rate [35]. Biochar product characteristics are heavily influenced by the extent of pyrolysis (pyrolytic temperature and residence pressure) and exclusively by biomass size and kiln or furnace residence time [32]. Mostly slow pyrolysis technology is used for trace metals removal in aqueous environment. Biochar produced by low pyrolysis processes has proven effective in the removal of contaminants (15 to 89\%) within a few minutes to days of residence time [36,37,38].

The vapour residence time is determined by the rate at which volatile and gases are removed in a kiln or furnace [35]. Prolonged residence time has secondary reactions thus the reactions of tar on biochar surfaces and charring of the tar instead of additional combustion or processing outside the kiln or furnace [39]. In gasification pyrolysis usually the biomass feedstock to some extent is oxidised in the gasification chamber at a temperature of about $800{ }^{\circ} \mathrm{C}$ of atmospheric or elevated pressure [39]. Basically, the main product of this process is gas hence, only few or no biochars, liquids, among others are formed.

It is obvious that typical solid product yields in gasification and fast pyrolysis process are considerably lower when compared with the solid product yields of flash carbonisation, hydrothermal carbonisation, slow pyrolysis, and torrefaction [35]. Dowie et al. [40] reported that yields of biochar products that ranged from 25 to $40 \mathrm{wt} \%$ and observed slightly decrease at higher pyrolysis temperature that was attributed to the volatilisation of other volatile products from the component of the biomass. The experimental pyrolysis was conducted at the heating rate of about $10 \mathrm{k} \mathrm{min}^{-1}$ up to the press cubed pyrolytic temperature ranging from 673 to $973 \mathrm{~K}$ [40].

Pellera et al. [41] also reported biochar yields of rice husk and compost derived after hydrothermal pyrolysis of about $62.5 \%$, and olive pomace and organic waste at a quite lower of $37.5 \%$. This revealed that the increase in pyrolytic temperature led to a decrease in the yield for all produced materials through the pyrolysis. To be precise, the yields of biochar at $300^{\circ} \mathrm{C}$ and $600^{\circ} \mathrm{C}$ were $31.9 \%$ and $32.8 \%$ for rice husks, $32.8 \%$ and $39.6 \%$ for orange waste, $26.7 \%$ and $39.3 \%$ for olive pomace, and $46 \%$ and $78.7 \%$ for compost, respectively [41]. Producing biochar at higher efficiency rate via slow pyrolysis by developing integrated systems is still at juvenile stage. Hence, the exploitation of the technology by researchers and other research centres and institutions is very minimal.

\section{Physico-chemical Characterisation of Biochar}

Generally, both the biomass feedstock and biochar produced can be subjected to physico-chemical analysis to come out with the basic characteristics of each raw and pyrolysed material. The biochars produced at different pyrolytic temperature usually will have honey-comb-like structure (Figure 1) because of the presence of cylindrical structures originally emanating from agricultural waste plant cells. The well-built pores of biochars aid its high Brunauer Emmett Teller (BET) surface area. The significance of pyrolytic temperature leads to the suggestion that biochar produced at high temperatures would lead to a material analogous to activated carbon in remediation of the environment [42]. It was deduced that the surfaces of low temperatures biochar can be hydrophobic, and could lessen its capacity to adsorb impurities. The nature, characteristics, quality, and potential use of biochar are affected by the form, type, preliminary steps of preparation and biomass feedstock size and type of pyrolysis product [43]. The initial ratio of exposure to total surface area of biochar could be affected by its size. A side this, biochar produced at low temperature is stronger than the one produced at high temperature, as its pores have great affinity for fine fractions (Figure 2). The chemical characteristics of individual feedstock and its biochar are always at significantly varying rate both spatially and temporarily [31]. It is indisputable that fixed carbon is the solid combustible residue that usually remains after a particle sample is carbonised and with volatile matter expelled [44]. Elemental ratios of oxygen/ carbon, oxygen/ hydrogen, and carbon/ hydrogen have been proven to be a reliable measure of both the extent of pyrolysis and level of oxidative adjustment of biochar in the solution systems $[45,46]$.

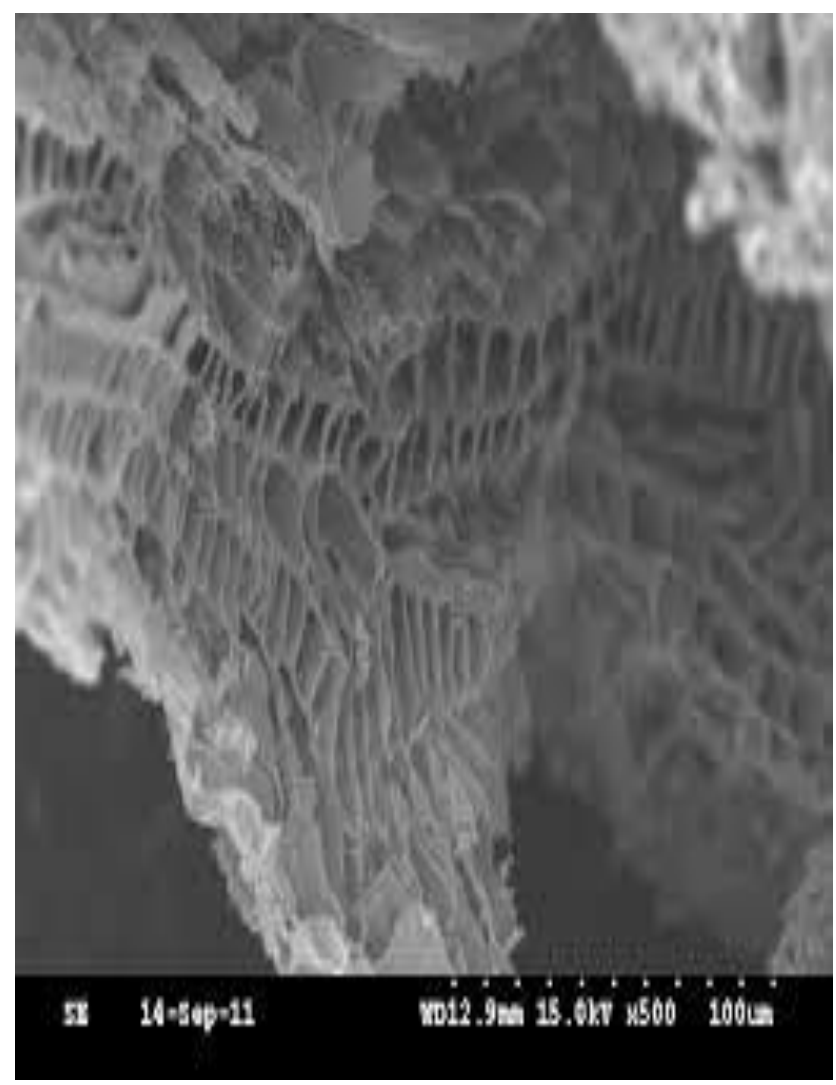

Figure 1. Honey comb like structure of biochar (Retrieved from www.biochar-international.org) 


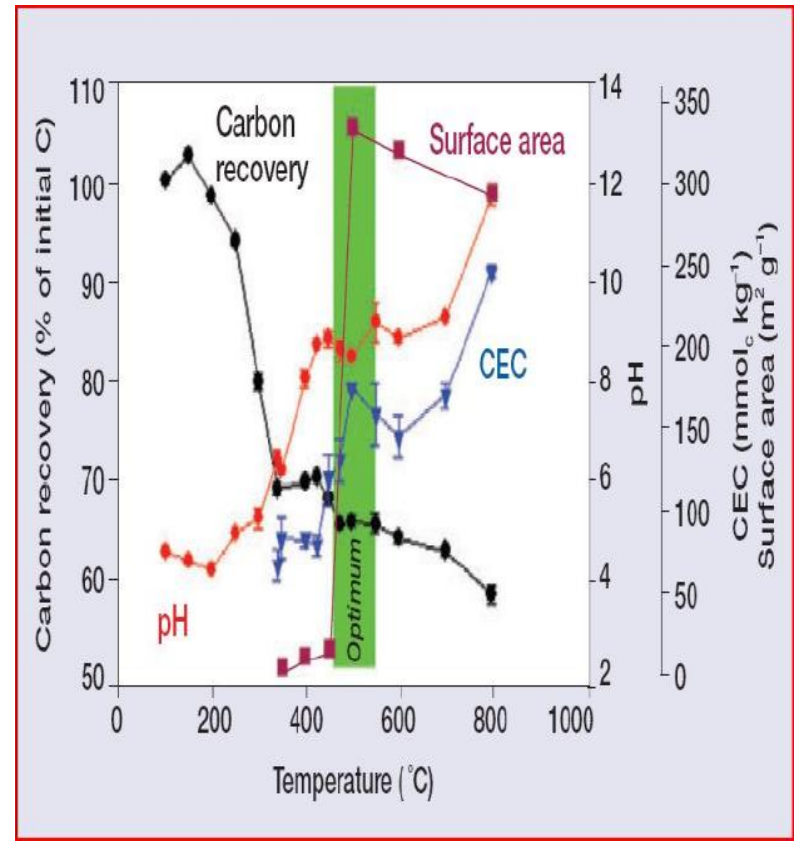

Figure 2. Biochar properties are largely dependent on the pyrolysis temperature (Adopted from Lehmann, 2007).

Cationic exchange capacity (CEC) basically is the measure of the surface charge in biochar that increases as the biochar ages [31] and has been recognised to an increase in some oxygenated functional groups on the surface of the biochar [47]. The most distinct change observed in biochar CEC values is as a result of time where it increased from $278 \mathrm{mmol}_{\mathrm{c}} \mathrm{kg}^{-1}$ to $518 \mathrm{mmol}_{\mathrm{c}} \mathrm{kg}^{-1}$, due to oxidation process created by hydroxyl and carboxylic acid functional groups [48]. The kind of biomass feedstock mainly influences the physico-chemical properties; pyrolytic temperature is the most significant process parameter; and biochar carbon content is not directly related to biochar yield.

\section{Biochar Adsorption of Trace Metals}

Biochar has proven effective and successful in removal of aqueous contaminants such as treatment of contaminated waste, contaminated water among others unlike any other carbonaceous fuel. In recent times, the most appropriate and cost-effective method of trace metals removal has proven to be adsorption using biochar $[21,26,49]$. However, the biochar nature, available and cost of production is crucial when remediating any aqueous phase such as land field waste water and polluted mining water. The adsorption mechanisms primarily involves chemical precipitation, electrostatic interaction, ionic exchange, and complexion with functional groups on biochar surface [20,31].

Mechanisms of trace metal adsorption in aqueous phases by biochar can be examined using different methods such as adsorption isotherms and desorption studies, industrial analysis and kinetic models. Sorption may involve the electrostatic attraction and inner sphere complex with free and alcoholic hydroxyl, phenolic hydroxyl groups or complexed carboxyl on biochar surface as well as superficial precipitation or coprecipitation [50]. Carboxyl (R-COOH) and alcoholic or phenolic hydroxyl groups $(\mathrm{R}-\mathrm{OH})$ have been recognised as the main groups contributing to coordination between trace metals and sorbent surface [51]. There is inadequate information on the factors that regulate the immobilisation of inorganic contaminants on biochar and the impact of biochar on trace metal retention in soils when compared with organic pollutants [49].

Studies utilising activated carbons (ACs) was based on the carbon type and the solution composition. The following mechanism dominate: electrostatic interaction between metal cations and negatively charged carbon surfaces (above $\mathrm{pH}_{\mathrm{pze}}$ of carbon); and ionic exchange between ionisable protons at the surface of the acidic carbonaceous adsorbent through exchange of proton ($\left.\mathrm{C} \pi-\mathrm{H}_{3} \mathrm{O}^{+}\right)$[41,52] or coordination of the d-electrons [24]. Impurities of mineral origin that include ash and basic nitrogen groups provide extra adsorption sites of the carbonaceous feedstock. Sorption is an endothermic physical process as revealed by the analysis of the thermodynamic parameters of metal sorption to biochars and activated carbons [20,53,54]. To be precise, an electrostatic interaction transpires between metal cations that are positively charged and that is $\pi$-electrons associated with either $\mathrm{C}=\mathrm{O}$ ligands or $\mathrm{C}=\mathrm{C}$ of a shared electron cloud on aromatic structures in biochar $[49,55,56]$. Researchers insinuated that biochar reduces $\mathrm{Pb}$ mobility as a result of the precipitation of insoluble $\mathrm{Pb}$-phosphates. Biochars produced from manure is said to be rich in phosphate [24].

Solution $\mathrm{pH}$ is an important factor that affects surface charge density of the adsorbent and the metal ion speciation [57]. Chen et al. [57] also reported that $\mathrm{pH}$ effects on the adsorption of $\mathrm{Cu}$ (II) and $\mathrm{Zn}$ (II) on biochar was highly significant and more pronounced for biochar derived from corn straw at $600^{\circ} \mathrm{C}$ and hardwood based biochar produced at $450^{\circ} \mathrm{C}$ [58]. It was revealed that the adsorption capacities $(\mathrm{mg} / \mathrm{g})$ of these biochars increased with corresponded increase in $\mathrm{pH}$ values of the test solution until it reaches its maximum at $\mathrm{pH}$ 5. Change in solution measurement of $\mathrm{pH}$ after biochar application and adsorption equilibrium revealed that both biochars had a buffering capacity that was distinguished from that of the electrolyte.

Biochar suitable for the removal of organic pollutants and trace metals is still approximate hence the need to explore more readily available and low cost biomass feedstock such as groundnut and shea nut shells for biochar production. Furthermore, most researches conducted to regulate organic pollution with carbonaceous feedstocks have been accomplished by equilibrium adsorption experiments [59]. Yet, soil column leaching experiments were shown to be more idyllic to simulate the actual situation of in situ soil organic pollution control and for the understanding of the probable use of carbonaceous materials to guard plant and groundwater [60].

Generally, sorption of organic and trace metal pollutants are influenced by multiple factors that include $\mathrm{pH}$ [61], particle size, time of exposure of pollutants, and soil moisture [62] and specific surface area [63]. Previous studies have shown that the adsorptive competition happens when multiple pollutants are adsorbed onto biochar. Inyang et al. [61] prepared two biochars from biomass that was digested anaerobically. The adsorptions 
of trace metals (thus $\mathrm{Cd}^{2+}, \mathrm{Cu}^{2+}, \mathrm{Pb}^{2+}$ and $\mathrm{Ni}^{2+}$ ) onto biochars were investigated [64]. It was deduced that the biochars have better ability for the removal of $\mathrm{Ni}^{2+}$ and $\mathrm{Cd}^{2+}$. The competitive adsorption between $\mathrm{Cu}$ (II) and $\mathrm{Zn}$ (II) onto biochars produced from pyrolysis of hardwood and corn straw transpired when the ion concentrations were kept at $1.0 \mathrm{mM} / \mathrm{L}$ [58]. The results reported by Uchimiya et al. [65] revealed that adsorption of deisopropylatrazine onto broiler litter biochar was inhibited in the presence of $\mathrm{Cu}$ (II) in binary solute tests.

\section{Mechanism of Interaction between Biochar and Trace Metals}

The unique characteristics of a biochar are due to its functional factors that include the type and size of feedstock biomass, conditions of pyrolysis and temperature. The wide variant unique characteristics of biochar make some particular raw materials more suitable than others for the adsorption of different trace metals. The choice of biochar for adsorption purposes should not only be based on aqueous environmental nature, trace metals concentrations, and multiple contaminations but also on physico-chemical properties of the biochar produced. The adsorption mechanism could be largely dependent on some properties of the biochar that included mineral composition, porosity of the structure, surface functional groups and specific surface area (Figure 3).

Some consideration that are crucial properties of biochar include ash, carbon contents, $\mathrm{pH}$ and surface area can be affected by post-treatments and therefore enhance their capability of immobilise trace metals [66]. Biochars act on bioavailable fraction of trace metals, which can reduce also their leachability. Hence, it is incumbent to review the mechanisms pertaining to the interaction between biochar and trace metal before application [67].

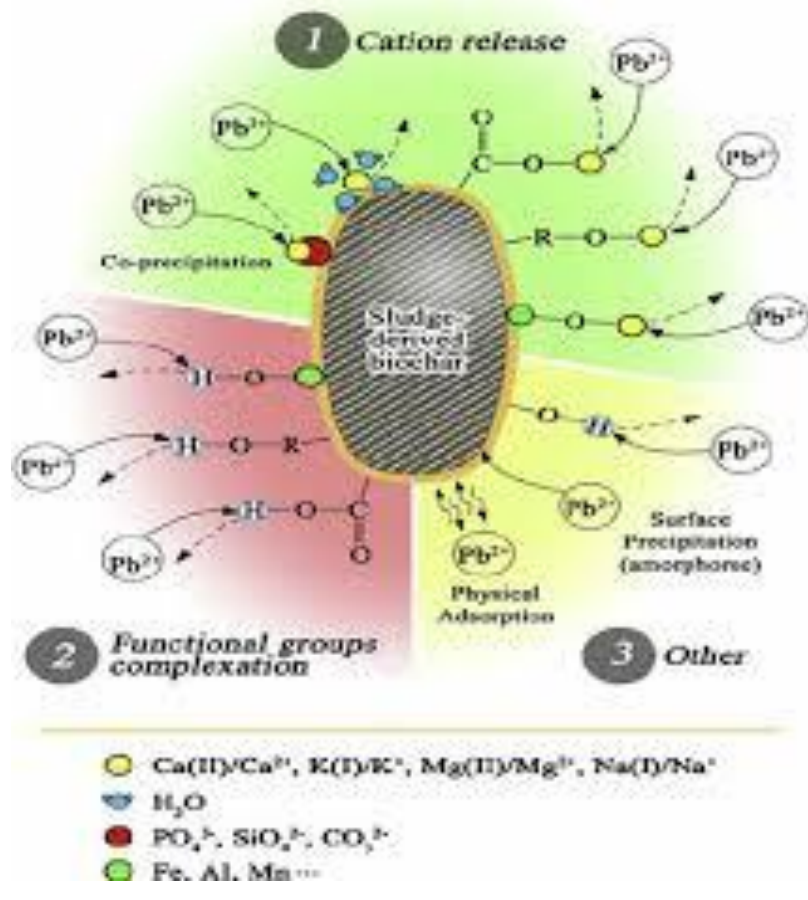

Figure 3. An illustration of the probable mechanisms of lead $(\mathrm{Pb})$ adsorption onto biochar (Adopted from Lu et al. 2012)
Trace metals have different and specific mechanisms of adsorption which is largely depended on the difference and the properties of biochars [68]. Many surface functional groups when exhibited on biochar's surface will likely influence its interactions with trace metals include electrostatic attraction, surface complexation and ion-exchange. These effects are demonstrated by the changes in functional groups of biochar before and after the metal ion adsorption [69].

Biochar with large surface area aids high adsorption capacity of complex trace metals on their surface. Surface sorption of trace metals on biochar has been proven on multiple studies using scanning electron microscopy $[22,26]$. This sorption can be due to different functional groups present as result of complexation of the trace metals in the biochar, and the exchange of trace metals with cations associated with biochar thus $\mathrm{Ca}^{2+}$ and $\mathrm{Mg}^{2+}$ [26], $\mathrm{K}^{+}, \mathrm{Na}^{+}$and $\mathrm{S}$ [70], or due to physical adsorption nature [26].

Lu et al. [26] also suggested that functional groups played an important role in $\mathrm{Pb}$ adsorption on biochar produced from sludge. This include metal exchange with $\mathrm{K}^{+}$and $\mathrm{Na}^{+}$due to the electrostatic outer-sphere complexation, inner-sphere complexation with free hydroxyl groups and surface complexation both carboxyl and hydroxyl functional groups being free. Similar mechanisms was observed in $\mathrm{Hg}$ (II) and $\mathrm{Cd}$ (II) adsorption onto biochar produced from soybean stalk [71] and corn straw [72], respectively. Also oxygen functional groups are noted to have stabilised trace metals in a biochar surface, mostly for softer acids like $\mathrm{Cu}^{2+}$ and $\mathrm{Pb}^{2+}$ $[67,70]$. Furthermore, $\mathrm{Cu}^{2+}$ adsorption was reported to have related to the higher oxygenated surface groups and also with high average pore diameter, higher superficial charge density and $\mathrm{Ca}^{2+}$ and $\mathrm{Mg}^{2+}$ exchange content of the biochar [73].

Biochar adsorption mechanisms of are mainly dependent on aqueous phases and the presents of cations in the aqueous environment and the biochar. Some other compounds present in the ash include carbonates, phosphates or sulphates $[49,74]$ can stabilise trace metals by precipitation of these compounds with the contaminants. Higher $\mathrm{pH}$ values after biochar addition can affect the rate and efficacy of adsorption of trace metal in aqueous environments. The pyrolysis temperature of biochar can increase their $\mathrm{pH}$ values [75], which is usually associated with ash content being at a higher proportion [76]. Biochar can also lessen the mobility of trace metals by altering their redox state [77]. It is possible for addition of biochar in aqueous environment to transform $\mathrm{Cr}^{6+}$ to a less mobile $\mathrm{Cr}^{3+}$ [77]. In spite of Houben et al. [60] suggestion that mechanism of trace metal immobilisation by different biochars is mostly affected by $\mathrm{pH}$, there a lot of unknown factors that largely contribute to trace metal immobilisation by different biochars.

Additionally, the mineral composition of the biochar played a great role in the adsorption process of the leaching solution. It was demonstrated by $\mathrm{Xu}$ et al. [78] that compared the concurrent removal effect of trace metals $(\mathrm{Cd}, \mathrm{Cu}, \mathrm{Pb}$ and $\mathrm{Zn})$ from aqueous phases using biochar produced from rice husk and dairy manure. In the study, the removal ability shows variation with diverse biochar feedstock sources and mineral components thus 
$\mathrm{CO}_{3}{ }^{2-}$ and $\mathrm{PO}_{4}{ }^{3-}$ originating from the feedstock play an important role in the biochar adsorption ability. In one of their studies that involve $\mathrm{Cd}, \mathrm{Cu}$ and $\mathrm{Zn}$ removal using biochar produced from dairy manure, show the biochar were rich in $\mathrm{CO}_{3}{ }^{2-}$ and $\mathrm{PO}_{4}{ }^{3}$. These serve as supplementary sites for adsorption leading to high adsorption capacity of the biochar for the trace metals [79].

However, biochar surface area and porosity in structure seem to have little effect on the trace metal adsorption ability than oxygen-containing functional groups [68]. Ding et al. [80] demonstrated that oxygen functional groups were perhaps responsible for the high $\mathrm{Pb}$ adsorption onto biochars produced at low temperature (250 and $400{ }^{\circ} \mathrm{C}$ ). Whilst intraparticle diffusion was mainly responsible for the low $\mathrm{Pb}$ adsorption on biochars pyrolysed at high temperature $\left(500\right.$ and $\left.600^{\circ} \mathrm{C}\right)$. Samsuri et al. [81] used biochar produced from oil palm and rice husk for adsorption of different trace metals. The study revealed that the biochar produced from oil palm with lower surface area shows a higher adsorption capacity for the trace metals than the rice husk. This implied that the surface area was less important than oxygen-containing functional groups.

A properly produced biochars could be very effective in the removal of trace metals from contaminated aqueous environment. The multiple factors that determine the adsorption of the trace metals in aqueous environment or phases need to be carefully examined. Cost-effectiveness of biomass feedstock and eco-friendliness of techniques need to also be given much consideration by way of making comparison with existing contaminant mitigation technologies.

\section{Co-exists of Contaminants}

The mixtures of trace metals exert significant influence on the equilibrium adsorption capacity mainly for the utilisation of biochar in the aqueous system. This is due to the complex pollutants co-existing in environment, which has interaction effects on the adsorption efficiency. The co-existed trace metals are studied for the better understanding of biochar adsorption mechanism of contaminants in the aqueous environment [68]. A study conducted on the adsorption ability of biochar for co-existed atrazine and simazine revealed the adsorption of the two contaminants decreased as they co-existed in the aqueous environment [58]. Similarly, phenanthrene (PHE) and Hg (II) co-existed in aqueous solution, resulted in direct competition in adsorption as each one suppressed another, leading to reduction in adsorption [71].

Nevertheless, Wang et al. [82] established co-existence of the humic acid and metal cations increased the polychlorinated biphenyls adsorption on the biochars. Besides, the particular mechanism that influences these still remains confusing. These inconsistencies suggest further researches engrossed on analysing the effects of competitive adsorption and ionic strength of biochars [68]. For the purpose of consistency with the real situation and good understanding of the influence mechanism, the cations and anions with their concentrations (ionic strength) in aqueous solution need to be thoroughly evaluated on an individual basis [68].
It is indisputable fact that most studies on adsorption of trace metals using biochar were mostly artificial aqueous phases like wastewater, which obviously remains gaps with the actual situation. The biochar application on actual aqueous environments treatment like landfill wastewater, polluted mining water, industrial sludge among others are still lacking. Besides, the influence of equilibrium adsorption capacity of complex pollutants and various ions co-existing in the aqueous environment is given little consideration.

\section{Dosage of Biochar Adsorbent}

The efficiency of adsorption is usually influence by the dosage of adsorbent. Hence, for effective and efficient removal of contaminants the ideal dosage of the biochar needs to be carefully chose and applied. A study by Chen et al. [57] revealed that increase in the biochar concentration lead to decrease the adsorption efficiencies. The highest observed trace metal adsorption efficiencies for biochars produced from hardwood and corn straw was at $1 \mathrm{~g} / \mathrm{L}$. Subsequently, increase in adsorbent concentration leads to the increase in total amount of active sites which improved the efficiency the removal of the total trace metals. Similarly, Tsai and Chen [83] reported that the number of adsorption sites increased in line with the increase in dosage of adsorbents (that is 0.10 to $0.30 \mathrm{~g} / \mathrm{L}$ ). Nonetheless, biochar produced from agricultural waste and other feedstock can shows adsorption efficiency that decreases as its mass increases.

\section{Sources of Trace Metals in Aqueous Environment}

Basically, the sources of trace metals in aqueous environment are natural and anthropogenic activities. These trace metals in aqueous environment have proven to have significantly deteriorated the quality of existing waters. Human exposure to trace metals can occur in numerous ways that ranged from the direct consumption of polluted food, exposure to air contaminated particles, and direct contact or ingestion of polluted water which accumulate over a period of time [84].

Naturally, rocks and volatiles of volcanic origins have contributed to increase in trace metals concentration in soils and waters in developed countries however minimal in developing countries especially Ghana. Activities volcanoes release trace metals that include aluminium, arsenic, copper, cadmium, mercury, magnesium, lead, zinc, rubidium among others. This is through diffusion of volcanic acidic gases via water penetrable rocks [85].

Naturally, soil erosion has also in multiple ways contributed to trace metal pollution in aqueous environment. The process via runoff release sedimentbound trace metals into aqueous environment. Water containing agrochemicals with toxic metals concentrations descend this sediment bound metal in the aqueous environment [86]. Mostly during run-off, some trace metal bound wastes are washed into poor drainage systems and subsequently into nearby aqueous environment [87] such as rivers, stream, among other surface water bodies in 
both developed and developing nations especially Ghana. In addition, some aerosol particles naturally contain smoke cloud and trace metals contaminants which usually accumulate on leaf surfaces via runoff they enter aqueous environment [88].

Major anthropogenic activities or source of trace metals in aqueous environment especially land field waste water, water bodies among others in both developed and developing countries include domestic and industrial waste, textiles activities, mining and extraction operations, metal finishing and electroplating, landfill leachates and nuclear power $[89,90]$. Metal finishing and electroplating contribute to release of toxic trace metal into aqueous environment. The process of cleaning tanks and wastewater treatment has proven to have generated substantial quantities of wet sludge contaminated with elevated toxic metals concentration [91]. Improper, disposal of domestic and industries solid and liquid wastes have contributed to trace metal contamination of aqueous phases in both developed and developing countries to which Ghana is no exception.

Basically, mining activities have been unpopular in countries endowed with minerals because it has demonstrated in multiple ways as source of toxic metals contributor in aqueous environment. Metal mining and smelting activities have contributed substantial amount of toxic metal contaminants in crops, vegetable, soil and water [92]. Additionally, textile industries have proven to be major sources of trace metal pollutants in aqueous environment in both developed and developing countries to which Ghana is no exception.

Landfill leachate that is produced as result of the waste degradation by the infiltrated water, in soluble form is organic and inorganic pollutants. The four major groups of pollutants in leachate include trace metals, dissolve organics matter, inorganic macro component and xenobiotic organic compounds [93].

Nuclear generating facilities mostly found in developing countries have proven to be a source of discharge of copper and zinc to aqueous environment. Due to the large amount consumption of water during and after operation, the nuclear effluent that is not free from trace metals are usually discharged into surface water and ground water bodies that pollute aqueous phases [94,95].

\section{Effect of Trace Metal Polluted Aqueous Environment}

Trace metals are noted for their deleterious human health effects that include cancer, nervous system damage, reduced growth and development, organ damage, and sometimes it could be fatal. Cadmium and lead exposure can cause development of autoimmunity resulting in attacking of its own cells in a person's immune system. This can result into diseases that include circulatory system, kidneys diseases, rheumatoid arthritis, nervous system, and fatal brain damage [96]. Elevated trace metals concentrations can cause permanent brain damage [96]. Almost every country has wastewater regulations to help lessen human and environmental exposure to toxicants this includes limits on trace metals concentrations and types found in the discharged wastewater [97].
Trace metals contamination is of great concern to human settings with high anthropogenic activities. They are injurious to humans due to their characteristics such as long biological half-lives, non-biodegradable nature and their ability to accumulate in different human body parts [98]. The continuous intake of trace metals by human populations via food chain have been reported in many countries and has now received attention from the general public as well as governmental agencies in developing countries [99]. Small-scale mining has enormously contributed to some nation's economy for some years now. However, it has also negatively affected the environment and human health [100]. As a result of the ever continuous introduction of harmful and toxic metals that includes As, $\mathrm{Cd}, \mathrm{Hg}, \mathrm{Pb}$ among others [101].

Untreated waste found in land fields may contain trace metal that usually leach into liquid ponds and leachates released into receiving aqueous environment that can cause environmental impact and human health problems [89]. Trace metal contaminants continue to serve as a major threat to aqueous environment and plants. The intake of toxic trace metals in corn products and vegetables amass in the kidney leading to its dysfunction. Studies have linked skeletal damage (osteoporosis) in humans to trace metals [102].

Trace metals polluted wastewater effluents on humans can include noxious (acute, sub-chronic and chronic), carcinogenic, teratogenic or mutagenic and neurotoxic [103]. The trace metals usually have their individual specific toxicity effects. Generally, the inhalation of vapours and ingestion of aluminium, arsenic, cadmium, copper, lead, mercury and zinc can result in poisoning, diarrhoea, gastrointestinal disorders, stomatitis, tremor, hemoglobinuria triggering a rust-red colour to human stool, ataxia, vomiting and convulsion, depression and pneumonia and paralysis [103]. Trace metals become only toxic in human systems as results of inability to metabolise and synthesise, and accordingly accumulate in human body particular the soft tissues [89]. For instance, lead has proven to be the number one health threat to children as its effects (child's growth, cause learning disabilities and damage the nervous system) can last a lifetime and has now been linked to crime and anti-social behaviour in children [104]. Lead toxicity is as a result of accumulation that can cause decrease in hemoglobin production, joint, kidney, reproductive and cardiovascular systems conditions and long-term impairment of the central and peripheral nervous systems $[105,106]$.

Cadmium is highly toxic trace metal regardless of its concentration levels in human beings. It has proven to be carcinogenic and persistently cumulative poison [107]. Cadmium exposure to humans at long terms causes renal dysfunction whilst elevated concentrations of exposure cause bone defects, cadmium pneumonitis, increased blood pressure, obstructive lung disease, osteomalacia, osteoporosis and spontaneous fractures and myocardic dysfunctions [103]. Its exposure concentration determines the symptoms such as abdominal cramps, nausea, vomiting, dyspnea and muscular weakness and at severe exposure cause pulmonary odema and fatal (death) [103,108,109].

Copper is indispensable nutrient to humans, however in elevated concentration in drinking water has proven to cause anaemia, liver cirrhosis in patients, liver and kidney 
damage. Human exposure to water contaminated with copper can cause disease burdens that include abdominal pain, development of anaemia, diarrhoea, headache and nausea in children, kidney and liver destruction and vomiting [104]. The maximum concentration limits standards, for some trace metals, established by USEPA [97] are summarised in Table 1.

\section{Adsorption of Adsorbents Produced from Agriculture Products}

In recent times many researcher have shown a great deal of interest in removing trace metals from industrial effluent have focused on using indigenous agricultural by-products with novelty as adsorbents [96]. This is often referred as bio-sorption in bioremediation of trace metal ions. This utilises non-living (inactive) microbial biomass to bind and concentrate trace metals from waste streams by only physical and chemical pathways (mainly adsorption and chelation) of uptake [110]. Biomass feedstock that include hazelnut shell, jackfruit, maize cob or husk, rice husk, groundnut shells, shea nut shells, moringa stem, coconut shells, dawadawa husks, pecan shells among others can potentially be used as an adsorbent for trace metal removal after chemical modification or conversion by heating into AC (activated carbon). Ajmal et al. [111] used peel of orange for Ni (II) removal from simulated wastewater and observed the maximum metal removal occurred at $\mathrm{pH}$ 6.0.

The removal of $\mathrm{Cr}$ (VI) done using modified coconut shell charcoal with chitosan and/ or oxidising agents for by Babel and Kurniawan [112]. Zn (II) and $\mathrm{Cu}$ (II) removal from raw wastewater was studied using pecan shells-activated carbon [113] and charcoal produced from potato peels [114]. Bishnoi et al. [115] studied Cr (VI) removal by rice husk-activated carbon from an aqueous solution and deduced that the maximum trace metal removal by rice husk occurred at $\mathrm{pH}$ of 2.0. Rice hull that contains cellulose, carbohydrate, lignin, and silica was used for Cr (VI) removal in simulated solution [116]. The adsorbent was modified with ethylenediamine to enhance its trace metal removal. The maximum $\mathrm{Cr}$ (VI) adsorption of $23.4 \mathrm{mg} / \mathrm{g}$ was observed at a $\mathrm{pH}$ of 2 . Table 2 is a summary of agricultural waste absorbents and adsorption capacity observed.

Table 1. Maximum concentration limits standards for the most harmful trace metals

\begin{tabular}{lll}
\hline Trace metal & Toxicities & MCL (mg/L) \\
\hline Arsenic & Skin manifestations, vascular disease, visceral cancers & 0.05 \\
Cadmium & Human carcinogen, kidney damage, renal disorder, & 0.01 \\
Chromium & Carcinogenic, diarrhoea, headache, nausea, vomiting, & 0.05 \\
Copper & Insomnia, liver damage, Wilson disease & 0.25 \\
Nickel & Chronic asthma, coughing, dermatitis, human carcinogen, nausea & 0.2 \\
Zinc & Depression, increased thirst, lethargy, and neurological signs & 0.8 \\
Lead & Circulatory system, damage the fetal brain, diseases of the kidneys, and nervous system & 0.006 \\
Mercury & Circulatory system, and diseases of the kidneys, and nervous system and rheumatoid arthritis & 0.00003 \\
\hline
\end{tabular}

(Source: Babel and Kurniawan 2003).

Table 2. Agricultural waste absorbents and adsorption capacity

\begin{tabular}{|c|c|c|c|c|c|}
\hline \multirow[b]{2}{*}{ Adsorbent } & \multicolumn{5}{|c|}{ Adsorption capacity (mg/g) } \\
\hline & $\mathrm{Pb}^{2+}$ & $\mathrm{Cd}^{2+}$ & $\mathrm{Cu}^{2+}$ & $\mathrm{Cr}^{6+}$ & References \\
\hline Brewer draff & & & 10.03 & & Trakal et al. (2014) \\
\hline Coconut shell charcoal & & & & 3.65 & Babel and Kurniawan (2004) \\
\hline Maize cope and husk & 456 & 493.7 & & & Igwe et al. (2005) \\
\hline Minced banana peel & 41.44 & & 20.97 & & Castro et al. 2011 \\
\hline Modified corn straw & & & 160 & & Song et al. 2014 \\
\hline Modified rice hull & & & & 23.4 & Tang et al. (2003) \\
\hline Nostoc spp & 93.5 & & & & Gupta and Rastogi (2008) \\
\hline Oedogonium spp & 145 & & & & Gupta and Rastogi (2008) \\
\hline Peanut straw/ rice straw & & & $38.4 / 15.5$ & & Tong and Xu (2013) \\
\hline Peanut straw/ soyabean straw & & & $89.0 / 52.8$ & & Tong et al. (2011) \\
\hline Rice husk & & 2 & & 0.79 & Bishnoi et al. (2003) \\
\hline Sunflower head carbon & & 25.0 & & 20.0 & Jain et al. (2015) \\
\hline Sunflower stem carbon & & 32.0 & & 28.0 & Jain et al. (2015) \\
\hline Ulva lactuca & & & & 112.3 & El-Sikaily et al. (2007) \\
\hline Wheat straw & 83.5 & 31.6 & & & Štefušová et al. (2012) \\
\hline
\end{tabular}


Some agricultural adsorbents that have proven effective and successful with high loading capacities of less than 90 $\mathrm{mg} / \mathrm{g}$ include aliginate carriers, Alcaligenes eutrophus, broad been peel, fig leaves, modified sugarcane bagasse, modified wheat bran, medlar peel, kraft lignin, Platanus orientalis, peas peel and rice husk [117]. The capacity of four inexpensive materials agriculture waste such as broad bean, fig leaves, medlar and peels of peas have been used for the removal of cadmium from aqueous solutions [118]. However, it was noted that biosorbents have shorter life time when compared with conventional sorbents [119]. Its early saturation thus metal interactive sites are being occupied [120]. The recyclable and decomposable properties of biomass usually delay their long-term utilisation for the adsorption processes [121]. The broad bean peel has proven to possess the maximum adsorption capacity for Cd (II). Moreover, sisal fibre (Agave sisalana) was used as a biosorbent for removal of $\mathrm{Pb}$ (II) and $\mathrm{Cd}$ (II) ions from natural waters [122].

A study on coconut shell (Cocos nucifera) powder has proven useful as a potential and good alternative for biosorption removal of trace metals [123]. A study by Alves and Coelho [124] using Moringa oleifera husks for adsorption of chromium in water has proven effective and successful. Husks of black gram (Cicer arientinum) were also studied as an alternative biosorbent of Cd (II) from aqueous solutions of low concentration [125]. Moreover, rice husk has been used for the removal and recovery of Cd (II) from waste waters by Ajmal et al. [126]. These give more room for more studies to be conducted using waste material such as groundnut shells and shea nut shells as biosorbents as only few are already used.

\section{Adsorption Isotherm}

Currently, one of the pervasive problems is the trace metals contamination in aqueous environment. This has be become one of the main focuses of research on the application of biochar for the removal of trace metals from contaminated water [68]. Adsorption isotherm is important in elevating the use of adsorbents since it vividly describes how adsorbates interact with adsorbents [127]. Some mathematical models have been used to describe the adsorption equilibrium of trace metals on the biochars and examine experimental data. Langmuir and Freundlich are frequently used.

Studies have deployed Langmuir and Freundlich models for fitting the equilibrium data. Langmuir model usually corresponds to homogeneous monolayer adsorption [128] whilst the Freundlich model clarifies the adsorption on the biochar adsorbent with surface being heterogeneous [129] as follows:

$$
\begin{gathered}
Q_{e}=\frac{Q_{\max } K_{l} C_{e}}{1+K_{l} C_{e}}=; \text { Langmuir model } \\
Q_{e}=\mathrm{K}_{\mathrm{F}} C_{e}^{1 / n} ; \text { Freundlich model }
\end{gathered}
$$

Where $\mathrm{Q}_{\mathrm{e}}$ and $\mathrm{C}_{\mathrm{e}}$ are equilibrium solid phase $(\mathrm{mg} / \mathrm{g})$ and liquid phase $(\mathrm{mg} / \mathrm{l})$ concentration of the trace metal respectively; $\mathrm{Q}_{\max }$ is the maximum adsorption capacity calculated using Langmuir model; $\mathrm{K}_{1}$ is the Langmuir constant $\left(1 \mathrm{mg}^{-1}\right)$; and $\mathrm{K}_{\mathrm{F}}\left(\mathrm{lg}^{-1}\right)$; and $\mathrm{n}$ (dimensionless) are Freundlich constants that signifies extent of the adsorption and the degree of nonlinearity between aqueous solution concentration and adsorption, respectively.

The results using these models are largely dependent on biochar properties and the target contaminant. The Langmuir isotherm usually assumes monolayer adsorption of the adsorbate on a surface of homogeneous adsorbent [130]. Chen et al. [57] studied adsorption isotherms at different initial of $\mathrm{Cu}$ (II) and $\mathrm{Zn}$ (II) that ranged from 0.1 to 5.0 $\mathrm{mM}$ that has proven that the Langmuir model $\left(\mathrm{R}^{2}>0.998\right)$ fit the data better than the Freundlich model $\left(\mathrm{R}^{2}\right.$ were 0.86-0.94). Many researchers also reported that adsorption of trace metals by biochar fits better to Freundlich than Langmuir isotherm in the dynamic data $[26,131,132,133]$.

The Freundlich isotherm discloses information on the heterogeneous adsorption and is not limited to the formation of a monolayer [130,134]. The study of $\mathrm{Cr}$ (VI) and $\mathrm{Pb}$ (II) adsorption by biochar pyrolysed from sludge of municipal wastewater, adsorption isotherms on the biochar were simulated with Langmuir and Freundlich equations. The study revealed that $\mathrm{Pb}$ (II) adsorption behaviour fitted better with Langmuir equation than Freundlich equation [131].

Biochar also showed high affinity for organic pollutants. In lately, many laboratory experiments were conducted to examine the potential of adsorbent from biochar for the removal of organic contaminants from aqueous environment. Overall, the results from these studies demonstrated that the biomass resultant char can be used as a cost-effective adsorbent for removal of environmental organic pollutants from the aqueous environment.

\section{Adsorption Kinetics}

The adsorption kinetics is used to establish the relationship with physical and/or chemical characteristics of the adsorbent biochar. The adsorption mechanism that may involve mass transport and chemical reaction processes are influenced by adsorption kinetics $[135,136]$. The knowledge of the kinetics of the process is necessary in a practical exploitation of biochar in removal of pollutants. The widely used kinetic models for the study of adsorption of contaminants by biochars include the intra-particle diffusion model, the pseudo-second-order kinetic model, and the pseudo-first-order kinetic model. Studies utilised the pseudo-second-order [137] model to describe the adsorption kinetics, thus:

$$
\frac{t}{Q_{t}}=\frac{1}{\mathrm{~K}_{2} Q_{2 \max }}+\frac{1}{Q_{\max }} t \text { Pseudo }- \text { second }- \text { order model (3) }
$$

Where $Q_{\text {max }}$ and $\mathrm{Q}_{t}$ referred to the adsorption capacities $(\mathrm{mg} / \mathrm{g})$ at the equilibrium and at time $\mathrm{t}$, respectively. These models offer important information that controlled the adsorption process involving adsorbent surface, chemical reaction, and/or diffusion mechanisms [138]. Most commonly used are the pseudo-first-order and pseudosecond-order kinetic models to study the adsorption of water contaminant onto biochars.

The pseudo-second-order kinetic model is usually centred on the postulation that the rate limiting step could 
be chemisorption that involves the valence forces through the exchange or sharing of electrons among adsorbent and adsorbate [139]. Lu et al. [26] study the kinetics of $\mathrm{Pb}^{2+}$ adsorption on biochar produced from sludge at initial $\mathrm{pH}$ of 2.0 to $5.0 \mathrm{pH}$-units. It was found to have been well fitted in the pseudo-second-order model that assumes chemisorption of the adsorbate on the adsorbent. Similar report was made by Liu and Zhang [20] that used the pseudo-first-order and pseudo-second-order models to study the lead adsorption mechanism on biochars produced from pinewood and rice husk. Kołodyn'ska et al. [135] also used $\mathrm{Cu}$ (II) and $\mathrm{Pb}$ (II) ions for studies of kinetic and adsorptive characterisation of biochar in trace metals removal that fitted well to the pseudo-second-order model. Khare et al. [69] removed different trace metals (thus $\mathrm{Cd}, \mathrm{Cr}, \mathrm{Cu}$ and $\mathrm{Pb}$ ) from acidic solutions using plant waste derived biochar. The study revealed that the adsorption of trace metals can be described more fittingly by the pseudo-second-order kinetics model than the firstorder kinetic model. This implied the rate limiting step may be the chemical adsorption. The pseudo-second-order model seems to fit well to most kinetic data for studied trace metals than pseudo- first-order.

\section{Factors Affecting Biosorption of Trace Metals}

A variety of multiple operation factors effect biosorption of trace metals these include adsorbent dosage, agitation speed, initial concentration of trace metal, temperature, particle size of adsorbent, effect of $\mathrm{pH}$ on the biosorption capacity and other factors [140]. It was reported by Chojnacka [140] that the biosorbent dosage decreases the quantity of biosorbed contaminant per unit weight of biosorbent that usually lead to increase in its removal efficiency whilst the initial contaminant concentration increases the quantity of biosorbed contaminant per unit weight of biosorbent which lead to decrease its removal efficiency. It was also noted that the $\mathrm{pH}$ of the solution could enhance biosorptive removal of cationic metals or basic dyes, nonetheless lessens that of anionic metals or acidic dyes. Basically temperature could enhance biosorptive removal of contaminants by increasing kinetic energy and surface activity of the adsorbate, however it can destroy the physical structure of the biosorbent.

Chojnacka [140] also reported that agitation speed could also enhance biosorptive removal rate of adsorptive contaminant by minimising its mass transfer resistance, nonetheless could damage the physical structure of the biosorbent. It was noted that ionic strength can reduce biosorptive removal of adsorptive contaminant due to completion with the adsorbate for binding sites of biosorbent. The particle size of the biosorbent could also favour the batch process due to its higher surface area, but not necessarily due the low in clogging and mechanical strength in the column process. In multiple pollutants concentrations situation the coexisting of the pollutants competes with a target pollutant for binding sites or forms any complex with it causing the higher concentration of other pollutants to reduce biosorptive removal of the target pollutant [140].

\section{Pre and Post Biochar Utilisation Problems}

Generally, biochars have proven to be technically effective and efficient as eco-friendly media for removal of organic and inorganic contaminant in aqueous environment such as polluted soil, water, waste effluents among others. It has also proven to have contained toxics in both organic and inorganic forms that are within acceptable limited and regulation standards after its production (Table 3). However, like any other remediation innovation biochars have their limitations that are not only about cost of production and technically in its utilisation but post utilisation issues. The source of raw material used for biochar has proven to be a source of dangerous components such as organic pollutants and trace metals that pose a potential risk to humans and their environment. Agricultural waste such as rice husk and rice straw utilised as biomass feedstocks for biochars generally contains elevated levels of silica, given their biochars ability to form crystalline silica. It has been established that biochars residues have the tendency to form poly aromatic hydrocarbons (PAHs) that are generally carcinogenic can be injurious to human health. The residues are the ash containing, those contaminants like trace metals, which after the utilisation researchers and their institutions face challenges of disposing them. Biochar used for removal of aqueous phases may not leave the aqueous environment to free from dangerous pathogens as it contains high carbon and nutrients that can stimulate their growth. Some agricultural wastes biochar also have the tendency of aiding the mobility of some of the metals in the aqueous environment.

\section{Conclusion}

Biochar production processes and its various applications can provide numerous benefits to both environment and economy for any developing or developed country. They utilisation of abundant agricultural wastes for adsorption of pollutants can improve human security and its environment. Since, it is a way of waste management and protecting the environment. However, biochars characteristics and properties are greatly affected by the original of feedstock, the pyrolysis process and its parameters. The adsorption capacity for trace metals is highly dependent on the experimental conditions that include adsorbent particle size, contact time, competing trace metals, dosage of biochar, $\mathrm{pH}$, metal concentration, and temperature of the leaching solution. Hence, understanding of the physico-chemical properties of any biochar and pyrolysis conditions is of great importance. Specifically designed biochars could be very effective in the removal of trace metals from aqueous contaminated environment. The multiple factors that determine the adsorption of the trace metals in aqueous environment or phases needs to be carefully examined. Cost-effectiveness of biomass feedstock and ecofriendliness of techniques need to also be given much consideration by way of making comparison with existing contaminant mitigation technologies. Previous researches 
have examined the relationships that exist between biochar production conditions, characteristics, and possible end-uses of biochar. However, there is paucity information available on post biochar utilisation consequences on the aqueous environment or issues arising from biochar usage on an aqueous environment.

\section{Conflict of Interest}

The authors of this article have no competing interest.

\section{Authors' Contributions}

$\mathrm{ABD}$, SJC and $\mathrm{NB}$ have contributed in the study conception and design, literature review and interpretation. $\mathrm{NB}, \mathrm{ABD}$ and SJC participated in drafting of manuscript and preparation of final version. All Authors have read the manuscript and have agreed to submit it in its current form for consideration for publication. All read and approved the final manuscript.

\section{Acknowledgements}

The authors are grateful to all researchers who works have been referenced in this review article for their immense contribution in the scientific world.

\section{References}

[1] European Biochar Certificate (EBC) (2012). Guidelines for a Sustainable Production of Biochar.' European Biochar Foundation (EBC), Arbaz, Switzerland.

http://www.europeanbiochar.org/en/download. Version $6.2 \mathrm{E}$ of $04^{\text {th }}$ February 2016

[2] Kajitani S, Tay LH, Zhang S, Li ZC (2013). Mechanisms and kinetic modelling of steam gasification of brown coal in the presence of volatile-char interactions. Fuel 103: 7-13.

[3] Mittal A, Thakur V, Gajbe V (2012). Evaluation of adsorption characteristics of an anionic azo dye brilliant yellow onto hen feathers in aqueous solutions. Environ. Sci. Pollut. R. 19(6): 2438-2447.

[4] Onundi YB, Mamun AA, AL Khatib MF, Ahmed YM (2010). Adsorption of copper, nickel and lead ions from synthetic semiconductor industrial wastewater by palm shell activated carbon. J. Environ. Sci. Tech. 7: 751-758.

[5] Lin SH (1993). Adsorption of disperse dye by various adsorbents J. Chem. Tech. Biotechnol. 58(2): 107-210.

[6] Lenntech $\mathrm{R}$ (2004). Water treatment and air purification. Available online:

http//www.excelwater.com/thp/filters/Water-Purification.htm (Accessed on 12 $2^{\text {th }}$ May, 2016).

[7] Subhashini V, Swamy AVVS (2013). Phytoremediation of $\mathrm{Pb}$ and $\mathrm{Ni}$ contaminated soils using Catharanthus roseus (L.). Universal J. Environ. Res. Technol 3: 465-472.

[8] Jadia CD, Fulekar MH (2008). Phytoremediation: the application of vermicompost to remove zinc, cadmium, copper, nickel and lead by sunflower plant. Environ. Engineer. Manage. J 7: 547-558.

[9] Ismail S, Khan F, Zafar Iqbal M (2013). Phytoremediation: Assessing tolerance of tree species against trace metal (PB and $\mathrm{CD}$ ) toxicity. Pakistan J Botany 45: 2181-2186.

[10] Adriano DC (2001). Trace elements in terrestrial environments: biochemistry, bioavailability and risks of metals. $2^{\text {nd }} E d$, SpringerVerlag, New York.

[11] Wuana RA, Okieimen FE (2011). Heavy metals in contaminated soils: A review of sources, chemistry, risks and best available strategies for remediation. Communicat Soil Sci. Plant Anal 42: 111-122.

[12] Parizanganeh AH, Bijnavand V, Zamani AA, Hajabolfath A (2012). Concentration, distribution and comparison of total and bioavailable trace metals in top soils of Bonab district in Zanjan province. Open J. Soil Sci 2: 123-132.

[13] Verheijen F, Jeffery S, Bastos AC, van der Velde, M, Diafas I (2010). Biochar application to soils. A critical scientific review of effects on soil properties processes and functions. JRC Sci. technic. report. pp 1-166.

[14] Angin D (2013). Effect of pyrolysis temperature and heating rate on biochar obtained from pyrolysis of safflower seed press cake. Bioresour. Technol 128: 593-597.

[15] Shivaram P, Leong YK, Yang H, Zhang DK (2013). Flow and yield stress behaviour of ultrafine Mallee biochar slurry fuels: the effect of particle size distribution and additives. Fuel 104: 326-332

[16] Demirbas A (2004). Effects of temperature and particle size on bio-char yield from pyrolysis of agricultural residues. J Analytical and Applied Pyrol 72(2): 243-248.

[17] Winsley P (2007). Biochar and bionenergy production for climate change. New Zealand Sci Rev 64 (1): 1-10.

[18] Yang L, Jin M, Tong C, Xie S (2013). Study of dynamic sorption and desorption of polycyclic aromatic hydrocarbons in silty-clay soil. J. Hazard. Mat 244-245: 77-85.

[19] Amonette JE, Jospeh S (2009). Characteristics of biochar: microchemical properties. In: J. Lehmann, Joseph, S. (Editor), Biochar for Environmental Management Science and Technology. Earthscan, London.

[20] Liu Z, Zhang F (2009). Removal of lead from water using biochars prepared from hydrothermal liquefaction of biomass. J. Hazard. Mat 167(1-3): 933-939.

[21] Tsai W, Liu S, Hsieh C (2012). Preparation and fuel properties of biochars from the pyrolysis of exhausted coffee residue. J. Anal. Applied Pyrol 93: 63-67.

[22] Beeseley L, Marmiroli M (2011). The immobilisation and retention of soluble arsenic, cadmium and zinc by biochars. Environ. Pollut 159(2): 474-480.

[23] Xu T, Lou L, Luo L, Cao R, Duan D, Chen Y (2012). Effect of bamboo biochar on pentachlorophenol leachability and bioavailability in agricultural soil. Sci. Tot. Environ 414: 727-731.

[24] Cao X, Harris W (2010). Properties of dairy-manure-derived biochar pertinent to its potential use in remediation. Bioresour. Technol 101(14): 5222-5228.

[25] Song W, Guo M (2012). Quality variations of poultry litter biochar generated at different pyrolysis temperatures. J Anal Applied Pyrol 94: 138-145.

[26] Lu H, Zhang W, Yang Y, Huang X, Wang S, Qiu R (2012). Relative distribution of $\mathrm{Pb}^{2+}$ sorption mechanisms by sludgederived biochars. Water R 46(3): 854-862.

[27] González-Chávez MC, Carrillo-González R, Gutiérrez-Castorena MC (2009). Natural attenuation in a slag heap contaminated with cadmium: The role of plants and arbuscular mycorrhizal fungi. J. Hazard. Mat 161: 1288-1298.

[28] De M, Azargohar R, Dalai AK, Shewchuk SR (2013). Mercury removal by bio-char based modified activated carbons. Fuel, 103: 570-578.

[29] Collison M, Collison L, Sakrabani R, Tofield B, Wallage Z (2009) Biochar and carbon sequestration: a regional perspective a report prepared for east of England development agency (EEDA). Project funded under the single programme - DA1 Carbon Reduction. Reference Number: 7049

[30] Spokas KA, Cantrell KB, Novak JM, Archer DA, Ippolito JA, Collins HP, Boateng AA, Lima IM, Lamb MC, McAloon AJ, Lentz RD, Nichols KA (2012). Biochar: A synthesis of its agronomic impact beyond carbon sequestration. J. Environ. Qual. 41: 973-989.

[31] Zhang M, Gao B, Varnoosfaderani S, Hebard A, Yao Y, Inyang M (2013). Preparation and characterization of a novel magnetic biochar for arsenic removal. Bioresour. Technol 130: 457-462.

[32] Asensio V, Vega FA, Andrade ML, Covelo EF (2013). Tree vegetation and waste amendments to improve the physical condition of copper mine soils. Chemosph 90(2): 603-610.

[33] Obemah DN, Baowei Z (2014). Biochar preparation, characterization, and adsorptive capacity and its effect on bioavailability of contaminants: An Overview. Adv. Mat. Sci. Engineer, Article ID 715398, 12 pages. 
[34] Agrafioti E, Bouras G, Kalderis D, Diamadopoulos E (2013). Biochar production by sewage sludge pyrolysis. J Anal Appl Pyrol. 101: 72.

[35] Meyer S, Glaser B, Quicker P (2011). Technical, economical, and climate-related aspects of biochar production technologies: a literature review. Environ. Sci. Technol 45(22): 9473-9483.

[36] Yao Y, Gao B, Inyang M, Zimmerman AR, Cao X, Pullammanappallil P, Yang L, (2011). Biochar derived from anaerobically digested sugar beet tailings: characterization and phosphate removal potential. Bioresour. Technol 102: 6273-6278.

[37] Ahmad M, Lee, SS, Dou X, Mohan D, Sung JK, Yang JE, Ok YS (2012). Effects of pyrolysis temperature on soybean stover-and peanut shell-derived biochar properties and TCE adsorption in water. Bioresour. Technol 118: 536-544.

[38] Chen Z, Chen B, Chiou CT (2012). Fast and slow rates of naphthalene sorption to biochars produced at different temperatures. Environ. Sci. Technol 46: 11104-11111.

[39] Oliver DP, Pan YF, Anderson JS, Lin TF, Kookana, RS, Douglas, GB, Wendling, LA (2013). Sorption of pesticides by a mineral sand mining by-product, neutralised used acid (NUA). Sci Tot Environ 442: 255-262

[40] Dowie A, Crosky A, Muroe P (2009). Physical properties of biochar, in BC for environmental management, J. Lehmann and S. Joseph, Eds., pp. 47-82, Earthscan, London, UK.

[41] Pellera FM, Giannis A, Kalderis D, Anastasiadou K, Stegmann R, Wang JY, Gidarakos E (2012). Adsorption of $\mathrm{Cu}$ (II) ions from aqueous solutions on biochars prepared from agricultural byproducts. J. Environ. Manage 96(1): 35-42.

[42] Gao Y, Yue Q, Gao B, Sun Y, Wang W, Li Q, Wang Y (2013). Preparation of high surface area-activated carbon from lignin of papermaking black liquor by $\mathrm{KOH}$ activation for $\mathrm{Ni}$ (II) adsorption. Chem. Engineer. J 217: 345-353.

[43] Harmsen J, Naidu R (2013). Bioavailability as a tool in site management. J. Hazard. Mat 261: 840-846.

[44] Dong XL, Ma LQ, Li YC (2011). Characteristics and mechanisms of hexavalent chromium removal by biochar from sugar beet tailing. J. Hazard. Mat. 190(1-3): 909-915.

[45] Haefele SM, Konboon Y, Wongboon W, Amarante S, Maarifat AA, Pfeiffer EM, Knoblauch C (2011). Effects and fate of biochar from rice residues in rice-based systems. Field Crops R 121(3): 430-440.

[46] Yu JT, Dehkhoda AM, Ellis N (2011). Development of biocharbased catalyst for transesterification of canola oil. Energ. Fuels 25(1): 337-344.

[47] Qiu Y, Zheng Z, Zhou Z, Sheng GD (2009). Effectiveness and mechanisms of dye adsorption on a straw-based biochars. Bioresour Technol 100(21): 5348-5351.

[48] Hale ES, Hanley K, Lehmann J, Zimmerman A, Cornelissen G (2011). Effects of chemical, biological, and physical aging as well as soil addition on the sorption of pyrene to activated carbon and biochars. Environ. Sci. Technol 45(24): 10445-10453.

[49] Cao X, Ma L, Gao B, Harris W (2009). Dairy-manure derived biochar effectively sorbs lead and atrazine. Environ. Sci. Technol 43(9): 3285-3291.

[50] Qiu R, Lu H, Zhang W, Yang Y, Huang X, Wang S (2012). Relative distribution of $\mathrm{Pb}^{2+}$ sorption mechanisms by sludgederived biochars. Wat. Res 46(3): 854-862.

[51] Wu M, Pan B, Zhang D, Xiao D, Li H, Wang C, Ning P (2013). The sorption of organic contaminants on biochars derived from sediments with high organic carbon content. Chemosph 90(2): 782-788.

[52] Kannan N, Rengasamy G (2005). Comparison of cadmium ion adsorption on various activated carbons. Water, Air, and Soil Pollut 163(1-4): 185-201.

[53] Uchimiya M, Lima IM, Klasson KT, Chang S, Wartelle LH, Rodgers JE (2010). Immobilization of heavy metal ions (Cu II, Cd II, Ni II, and $\mathrm{Pb}$ II) by broiler litter-derived biochars in water and soil. J. Agric. and Food Chem 58(9): 5538-5544.

[54] Harvey OR, Herbert BE, Rhue RD, Kuo L (2011). Metal interactions at the biochar-water interface: Energetics and structure-sorption relationships elucidated by flow adsorption microcalorimetry. Environ. Sci. Technol 45(13): 5550-5556.

[55] Swiatkowski A, Pakula M, Biniak S, Walczyk M (2004). Influence of the surface chemistry of modified activated carbon on its electrochemical behaviour in the presence of lead (II) ions. Carbon 42(15): 3057-3069.
[56] Uchimiya M, Wartelle LH, Lima IM, Klasson KT (2010). Sorption of deisopropylatrazine on broiler litter biochars. J. Agric. Food Chem. 58(23): 12350-12356.

[57] Chen X, Chen G, Chen L, Chen Y, Lehmann J, McBride MB, Hay AG (2011). Adsorption of copper and zinc by biochars produced from pyrolysis of hardwood and corn straw in aqueous solution. Bioresour. Technol 102(19): 8877-8884.

[58] Zheng W, Guo M, Chow T, Bennett DN, Rajagopalan N (2010). Sorption properties of greenwaste biochar for two triazine pesticides. J. Hazard. Mat 181(1-3): 121-126.

[59] Lou L, Luo L, Cheng G, Wei Y, Mei R, Xun B, Xu X, Hu B, Chen Y. (2012). The sorption of pentachlorophenol by aged sediment supplemented with black carbon produced from rice straw and fly ash. Bioresour. Technol 112: 61-66.

[60] Houben D, Evrard L, Sonnet P (2013). Mobility, bioavailability and $\mathrm{pH}$-dependent leaching of cadmium, zinc and lead in a contaminated soil amended with biochars. Chemosph 92(11): 1450-1457.

[61] Inyang M, Gao B, Ying Yao Y, Yingwen Xue Y, Zimmerman AR Pullammanappallil P, Cao X (2012). Removal of trace metals from aqueous solution by biochars derived from anaerobically digested biomass. Bioresour Technol 110: 50-56.

[62] Subramanian B, Namboodiri V, Khodadoust AP, Dionysiou DD (2010). Extraction of pentachlorophenol from soils using environmentally benign lactic acid solutions. J. Hazard. Mat 174(1-3): 263-269.

[63] Rhodes AH, Carlin A, Semple KT (2008). Impact of black carbon in the extraction and mineralization of phenanthrene in soil. Environ. Sci. Technol 42(3): 740-745.

[64] Yu X, Ying G, Kookana RS (2009). Reduced plant uptake of pesticides with biochar additions to soil. Chemosph 76(5): 665-671.

[65] Uchimiya M, Cantrell KB, Hunt PG, Novak JM, Chang S (2012). Retention of heavy metals in a Typic Kandiudult amended with different manure-based biochars. J. Environ. Qual. 41: 1138-1149.

[66] Lima IM, Boykin DL, Klasson KT, Uchimiya M (2014). Influence of post-treatment strategies on the properties of activated chars from broiler manure, Chemosph 95: 96-104.

[67] Paz-Ferreiro J, Lu H, Fu S, Méndez A, Gascó G (2014). Use of phytoremediation and biochar to remediate trace metal polluted soils: a review. Solid Earth, 5: 65-75.

[68] Tana X, Liua Y, Zenga G, Wang X, Hua X, Gua Y, Yanga Z (2015). Review Application of biochar for the removal of pollutants from aqueous solutions. Chemosphere 125: 70-85.

[69] Khare P, Dilshad U, Rout PK, Yadav V, Jain S (2013). Plant refuses driven biochar: application as metal adsorbent from acidic solutions. Arab. J. Chem.

[70] Uchimiya M, Chang SC, Klasson, KT (2011). Screening biochars for heavy metal retention in soil: Role of oxygen functional groups J. Hazard. Mater, 190: 432-444.

[71] Kong H, He J, Gao Y, Wu H, Zhu X (2011). Cosorption of phenanthrene and mercury (II) from aqueous solution by soybean stalk-based biochar. J. Agric. Food. Chem 59: 12116-12123.

[72] Sun J, Lian F, Liu Z, Zhu L, Song Z (2014). Biochars derived from various crop straws: characterization and $\mathrm{Cd}$ (II) removal potential. Ecotoxicol. Environ. Saf 106: 226-231.

[73] Méndez A, Barriga S, Fidalgo JM, Gascó G (2009). Adsorbent materials from paper industry waste materials and their use in $\mathrm{Cu}$ (II) removal from water. J. Hazard. Mater. 165: 736-743.

[74] Park J, Hung I, Gan Z, Rojas OJ, Lim KH, Park S (2013). Activated carbon from biochar: influence of its physicochemical properties on the sorption characteristics of phenanthrene. Bioresource Technology 149: 383-389.

[75] Wu W, Yang M, Feng Q, McGrouther K, Wang H, Lu H, Chen Y (2012). Chemical characterization of rice straw-derived biochar for soil amendment. Biomass Bioenerg. 47: 268-276.

[76] Cantrell KB, Hunt PG, Uchimiya M, Novak JM, Ro KS (2012). Impact of pyrolysis temperature and manure source on physicochemical characteristics of biochar. Bioresour. Technol 107: 419-428.

[77] Choppala GK, Bolan NS, Megharaj M, Chen Z, Naidu R (2012). The influence of biochar and black carbon on reduction and bioavailability of chromate in soils. J. Environ. Qual. 41:1175-1184.

[78] Xu X, Cao X, Zhao L, Wang H, Yu H, Gao B (2013). Removal of $\mathrm{Cu}, \mathrm{Zn}$, and $\mathrm{Cd}$ from aqueous solutions by the dairy manurederived biochar. Environ. Sci. Pollut. Res 20: 358-368. 
[79] Xu X, Cao X, Zhao L (2013). Comparison of rice husk-and dairy manure-derived biochars for simultaneously removing heavy metals from aqueous solutions: role of mineral components in biochars. Chemosph 92: 955-961.

[80] Ding W, Dong X, Ime IM, Gao B, Ma LQ (2014). Pyrolytic temperatures impact lead sorption mechanisms by bagasse biochars. Chemosph 105: 68-74.

[81] Samsuri A, Sadegh-Zadeh F, Seh-Bardan B (2014). Characterization of biochars produced from oil palm and rice husks and their adsorption capacities for heavy metals. Int. J. Environ. Sci. Technol 11: 967-976.

[82] Wang Y, Wang L, Fang G, Herath H, Wang Y, Cang L, Xie Z, Zhou D (2013). Enhanced PCBs sorption on biochars as affected by environmental factors: humic acid and metal cations. Environ. Pollut 172: 86-93.

[83] Tsai WT, Chen HR (2013). Adsorption kinetics of herbicide paraquat in aqueous solution onto a low-cost adsorbent, swinemanure-derived biochar. International Journal of Environmental Science and Technology 10: 1349-1356.

[84] United Nations Environmental Protection and Global Program of Action (2004). Why the marine environment needs protection from trace metals. Available online: http://www.oceansatlas.org/ unatlas/uses/uneptextsph/wastesph/2102gpa (Accessed on 12 $2^{\text {th }}$ May, 2016).

[85] Amaral A, Cruz JV, Cunha RT, Rodrigues A (2006). Baseline levels of metals in volcanic soils of the Azores (Portugal). J. Soil and Sediment Contaminat 15:123-130.

[86] Kaizer AN, Osakwe SA (2010). Physicochemical characteristics and heavy metal levels in water samples from five river systems in Delta State, Nigeria. J. Applicat. Sci. Environ. Manage 14(1): 83-87.

[87] Taiwo AM, Adeogun AO, Olatunde KA, Adegbite KI (2011). Analysis of groundwater quality of hand-dug wells in peri-urban areas of Obantoko, Abeokuta, Nigeria for selected physicochemical parameters. Pacific J. Sci. Technol 12(1): 527-534.

[88] Sardar K, Ali S, Hameed S, Afzal S, Fatima S, Shakoor MB, Bharwana SA, Tauqeer HM (2013). Heavy metals contamination and what are the impacts on living organisms. Greener J Environ. Manag. and Public Saf (4): 172-179.

[89] Akpor OB, Ohiobor GO, Olaolu TD (2014). Trace metal pollutants in wastewater effluents: sources, effects and remediation. Adv. Biosci. Bioengineer 2(4): 37-43.

[90] Eman NA, Sabreen RA, Mashita MY, Md Lutfor R (2015) Environmentally friendly biosorbent from Moringa oleifera leaves for water treatment. Int. J. Environ. Sci. Develop 6(3): 165-169.

[91] Cushnie GC (1985). Electroplating wastewater pollution control technology. Noyes Publication: New Jersey: pp. 375-377.

[92] Wei C, Wang C, Yang L (2008). Characterising spatial distribution and sources of heavy metals in the soils from mining-smelting activities in Shuikoushan Hunan Province. China. J Environ Sci 21: 1230-1236.

[93] Christensen TH, Kjeldsen P, Bjerg PL, Jensen DL, Christensen JB, Baun A, Albrechtsen HJ, Heron G (2001). Biogeochemistry of landfill leachate plumes. Applied geochemistry 16: 659-718.

[94] Hagberg L, Lofgren E (2007). Soil and plant contamination by textile industries at ZFILM, Managua. Project work in aquatic and environmental engineering, 10 ECTS, Uppsala University Project course, 10 ECTS, Swedish University of Agricultural Sciences.

[95] Begum RA, Zaman MW, Mondol AT, Ismal MS, Hossain KMF (2011). Effects of textile industrial wastewater and uptake of nutrients on the yield of rice. Bangladesh J. Agric. Res 36(2): 319-331.

[96] Barakat MA (2011). New trends in removing heavy metals from industrial wastewater. Review Article. Arabian J. Chem 4: 361-377.

[97] Babel S, Kurniawan TA (2003). Low cost adsorbent for trace metals uptake from contaminated water. Hazard Mat 97: 219-243.

[98] Monu A, Bala K, Shweta R, Anchal R, Barinder K, Neeraj M (2008). Heavy metal accumulation in vegetables irrigated with water from different sources.

[99] Ejaz ul I, Yang X, He ZL, Mahmood Q (2007). Assessing potential dietary toxicity of trace metals in selected vegetables and food crops. J. Zhejiang Univ. Sci. B, 8(1): 1-13.

[100] Aryee BNA, Ntibery BK, Atorkui E (2003). Trends in the smallscale mining of precious mineralsin Ghana: A perspective on its environmental impact. J. Clean Prod. 11: 131-140.
[101] Paruchuri Y, Siuniak A, Johnson N, Levin E, Mitchell K, Goodrich JM, Renne EP, Basu N (2010). Occupational and environmental mercury exposure among small-scale gold miners in the Talensi-Nabdam District of Ghana's Upper East region. Sci. Total Environ. 408: 6079-6085.

[102] Abdullahi MS (2013). Toxic effects of lead in humans: an overview. Global Adv. J. Environ. Sci. Toxicol 2(6): 157-162.

[103] Duruibe JO, Ogwuegbu MOC, Egwurugwu JN (2007). Trace metal pollution and human biotoxic effects. Int. J. Physical Sci 2(5): $112-118$

[104] Salem HM, Eweida EA, Farag A (2000). Heavy metals in drinking water and their environmental impact on human health. ICEHM, 2000: 542-556.

[105] Nolan K (2003). Copper toxicity syndrome. J. Orthomolecular Psychiatry, 12: 270-282.

[106] Galadima A, Garba ZN (2012). Heavy metals pollution in Nigeria: causes and consequences. Elixir J. Pollut 45: 7917-7922.

[107] Lin X, Burns RC, Lawrance GA (2005). Heavy metals in wastewater: the effect of electrolyte composition on the precipitation of cadmium (II) using lime and magnesia. Water, Air and Soil Pollut 165: 131-152.

[108] European Union (2002). Heavy metals in wastes. European Commission on Environment. Available at: http://ec.europa.eu/environment/waste/studies/pdf/heavy_metalsre port.pdf.

[109] Young RA (2005). Toxicity profiles: toxicity summary for cadmium, risk assessment information system, RAIS, University of Tennessee. Available at www.rais.ornl.gov/tox/profiles/cadmium.shtml.

[110] Igwe JC, Ogunewe DN, Abia AA (2005). Competitive adsorption of $\mathrm{Zn}$ (II), $\mathrm{Cd}$ (II) and $\mathrm{Pb}$ (II) ions from aqueous and non-aqueous solution by maize cob and husk. Afr. J. Biotechnol. 4(10): 11131116.

[111] Ajmal M, Rao R, Ahmad R, Ahmad J (2000). Adsorption studies on Citrus reticulata (fruit peel of orange) removal and recovery of $\mathrm{Ni}$ (II) from electroplating wastewater. J. Hazard. Mater. 79: 117-131.

[112] Babel S, Kurniawan TA (2004). Cr (VI) removal from synthetic wastewater using coconut shell charcoal and commercial activated carbon modified with oxidizing agents and/or chitosan. Chemosph 54 (7): 951-967.

[113] Bansode PR, Losso JN, Marshall WE, Rao RM, Portier RJ (2003). Adsorption of metal ions by pecan shell-based granular activated carbons. Bioresour. Technol. 89: 115-119.

[114] Amana T, Kazi AA, Sabri MU, Banoa Q (2008). Potato peels as solid waste for the removal of trace metal copper (II) from waste water/industrial effluent. Colloids Surf. B: Biointerfaces 63: 116-121.

[115] Bishnoi NR, Bajaj M, Sharma N, Gupta A (2003). Adsorption of $\mathrm{Cr}$ (VI) on activated rice husk carbon and activated alumina. Bioresour. Technol. 91(3): 305-307.

[116] Tang P, Lee CK, Low KS, Zainal Z (2003). Sorption of Cr (VI) and $\mathrm{Cu}$ (II) in aqueous solution by ethylenediamine modified rice hull. Environ. Technol. 24: 1243-1251.

[117] Rao KS, Mohapatra M, Anand S, Venkateswarlu P (2010). Review on cadmium removal from aqueous solutions. Int. J. Engineer, Sci. and Technol 2(7): 81-103.

[118] Benaissa H (2006). Screening of new sorbent materials for cadmium removal from aqueous solutions. Hazard Mat 132: 189-195.

[119] Fu F, Wang Q (2011). Removal of heavy metal ions from wastewaters: A review. J. Environ. Manage 92: 407-418.

[120] Gadd GM (2008). Accumulation and transformation of metals by microorganisms, biotechnology set, Wiley-VCH Verlag $\mathrm{GmbH}$, 225-264 pp.

[121] Sahmoune MN, Louhab K, Boukhiar A (2011). Advanced biosorbents materials for removal of chromium from water and wastewaters. Environ. Prog. Sust. Energ 30: 284-293.

[122] dos Santos WNL, Cavalcante DD, da Silva EGP, das Virgens CF, Dias FDS (2011). Biosorption of $\mathrm{Pb}$ (II) and $\mathrm{Cd}$ (II) ions by Agave sisalana (sisal fiber). Microchem. J 97: 269-273.

[123] Pino GH, de Mesquita LMS, Torem MML, Pinto GAS (2006). Biosorption of cadmium by green coconut shell powder. Miner. Eng. 19: 380-387.

[124] Alves VN, Coelho NMM (2013). Selective extraction and preconcentration of chromium using Moringa oleifera husks as 
biosorbent and flame atomic absorption spectrometry. Microchem. J 109: 16-22.

[125] Saeed A, Iqbal M (2003). Bioremoval of cadmium from aqueous solution by black gram husk (Cicer arientinum). Wat. Res 37: 3472-3480.

[126] Ajmal M, Rao RAK, Anwar S, Ahmad J, Ahmad R (2003). Adsorption studies on rice husk: removal and recovery of Cd (II) from wastewater. Bioresour. Technol. 86: 147-149.

[127] Goh KH, Lim TT, Dong Z (2008). Application of layered double hydroxides for removal of oxyanions: a review. Water $\mathrm{R} 42$ : 1343-1368.

[128] Langmuir I (1918). The adsorption of gases on plane surfaces of glass, mica and platinum. J. Am. Chem. Soc. 40: 1361-1403.

[129] Freundlich HMF (1906). Uber die adsorption in losungen. Z Phys Chem 57: 385-470.

[130] Hu XJ, Wang JS, Liu YG, Li X, Zeng GM, Bao ZL, Zeng XX, Chen AW, Long F (2011). Adsorption of chromium (VI) by ethylenediamine-modified cross- linked magnetic chitosan resin: isotherms, kinetics and thermodynamics. J. Hazard. Mater 185: 306-314.

[131] Zhang W, Mao S, Chen H, Huang L, Qiu R (2013). Pb (II) and Cr (VI) sorption by biochars pyrolyzed from the municipal wastewater sludge under different heating conditions. Bioresour. Technol 147: 545-552.

[132] Agrafioti E, Kalderis D, Diamadopoulos E (2014). Arsenic and chromium removal from water using biochars derived from rice husk, organic solid wastes and sewage sludge. J. Environ. Manage. 133: 309-314.

[133] Yang Y, Lin X, Wei B, Zhao Y, Wang J (2014). Evaluation of adsorption potential of bamboo biochar for metal-complex dye: equilibrium, kinetics and artificial neural network modeling. Int. J. Environ. Sci. Technol 11: 1093-1100.

[134] Kim WK, Shim T, Kim YS, Hyun S, Ryu C, Park YK, Jung J (2013). Characterization of cadmium removal from aqueous solution by biochar produced from a giant Miscanthus at different pyrolytic temperatures. Bioresour. Technol 138: 266-270.

[135] Kołodyn'ska D, Wne trzak R, Leahy J, Hayes M, Kwapin 'ski W, Hubicki Z (2012). Kinetic and adsorptive characterization of biochar in metal ions removal. Chem. Eng. J. 197: 295-305.

[136] Boutsika LG, Karapanagioti HK, Manariotis ID (2014). Aqueous mercury sorption by biochar from malt spent rootlets. Water, Air, Soil Pollut 225: 1-10.

[137] Ho YS, McKay G (1998). Kinetic models for the sorption of dye from aqueous solution by wood. Process Saf Environ Prot 76(B2): 183-191.
[138] Reddy D, Lee SM (2013). Application of magnetic chitosan composites for the removal of toxic metal and dyes from aqueous solutions. Adv. Colloid Interface Sci 201: 68-93.

[139] Ho YS, McKay G (1999). Pseudo-second order model for sorption processes. Process Biochem 34: 451-465.

[140] Chojnacka K (2010). Biosorption and bioaccumulation - the prospects for practical applications. Environ Int 36: 299-307.

[141] Trakal L, Sigut R, Sillerova H, Faturikova D, Komarek M (2014). Copper removal from aqueous solution using biochar: Effect of chemical activation. Arab. J Chem 7: 43-52.

[142] Castro RSD, Caetano L, Ferreira G, Padilha PM, Saeki MJ, Zara LF, Martines MAU, Castro GR (2011). Banana peel applied to the solid phase extraction of copper and lead from river water: Preconcentration of metal ions with a fruit waste. Industrial and Engineering Chemistry Research 50(6): 3446-3451.

[143] Song Z, Lian F, Yu Z, Zhu L, Xing B, Qiu W (2014). Synthesis and characterization of a novel $\mathrm{MnO}_{\mathrm{x}}$-loaded biochar and its adsorption properties for $\mathrm{Cu}^{2+}$ in aqueous solution. Chemical Engineering Journal, 242: 36-42

[144] Gupta VK, Rastogi A (2008). Biosorption of lead (II) from aqueous solutions by non-living algal biomass Oedogonium spp. and Nostoc spp. a comparative study. Colloids Surf. B: Biointerfaces, 64: 170-178.

[145] Tong X, Xu R (2013). Removal of $\mathrm{Cu}$ (II) from acidic electroplating effluent by biochars generated from crop straws. J. Environ. Sci. 25: 652-658.

[146] Tong X, Li J, Yuan J, Xu R (2011). Adsorption of Cu (II) by biochars generated from three crop straws. Chem. Eng. J. 172: 828-834.

[147] Jain M, Garg VK, Kadirvelu K, Sillanpa“a”, M (2015). Adsorption of heavy metals from multi-metal aqueous solution by sunflower plant biomass-based carbons. Int. J. Environ. Sci. Technol ISSN 1735-1472. Int. J. Environ. Sci. Technol.

[148] El-Sikaily A, El Nemr A, Khaled A, Abdelwehab O (2007). Removal of toxic chromium from wastewater using green alga Ulva lactuca and its activated carbon. J. Hazard. Mater. 148: 216-228.

[149] Štefušová, K. Lovás M, Zubrik A, Matik M, Václavíková M (2012). Removal of $\mathrm{Cd}^{2+}$ and $\mathrm{Pb}^{2+}$ from aqueous solutions using bio-char residues. Nova Biotechnologica Et Chimica 11(2): 139-146.

[150] Mirimichi Green - ECO. 2016. Effective earth solution. Environ. Services.

[151] www.biochar-international.org. September 19 (2014). Rebuilding "Who-ville" - Our Lost and Forgotten Underworld Communities.

[152] Lehmann J (2007). Bioenergy in the black. Front Ecol. Environ 5(7): 381-387. 